\title{
IMPLEMENTATION OF INVENTORY METHOD IN IMPROVING VISUAL STUDENTS VISUAL LEARNING ON NATURAL RESPONSIBILITY RESOURCES AND ENVIRONMENTAL SURVIVAL Tresna Nurhayati
}

\author{
Cibabat Mandiri Primary School 3, Cimahi City, West Java, Indonesia \\ tresna.nurhayati45@gmail.com
}

\begin{abstract}
The main issues of this research are how to improve the visual abilities of Elementary School (ES) students on Natural Resources (NR) and Environment (EN) subjects through the method of discovery. The objectives of the research are as follows: (1). Improving visual abilities of elementary students through discovery methods; (2). Provides learning through fun discovery methods and can inspire elementary students. The methods / approaches used in achieving the following objectives: $(a)$. Collect students and elementary teachers involved in research; (B). Provide an overview of the research activities to be undertaken; $(C)$. Reflecting on, discussion of learning by method of discovery; (D). Collaborate with elementary teachers in the determination of experimental class and control class; $(E)$. Implementation of learning method of discovery; $(F)$. Evaluation of learning by method of discovery. The results showed that there was an increase in visual ability of elementary school students through learning with the method of discovery of 24\%; (2). Elementary students are enthusiastic about learning by the method of discovery given by the teacher; (3). The occurrence of collaboration between one student and another student at the time of learning by the method of discovery is done.
\end{abstract}

Keywords: Learning, Invention Method, Visual.

\section{INTRODUCTION}

This research was conducted to find out the relationship between discovery method and the students' visual ability in improving the learning for the 2 nd grade students in elementary school especially in Social Science learning (IPS) considering that nowadays a lot of learning is done in elementary school only by using lecture or demonstration method Alone especially for low-grade classes.

Given that the curriculum of learning in schools now turns into a National Curriculum that refers to student-centered learning (Student Center), Teacher Center is not the only teacher and the teacher only as a classroom learning facilitator. In the National curriculum, students must further explore the learning or science based on the theme and the learning process must be done so that students gain direct experience in the learning process. As in the learning activities so many learning methods that we can do to make the students more interested in learning activities at school and explore it at home. Here the researchers will use one of the methods of learning is the discovery method of discovery or learning to further explore the interest of students on social studies learning.

Based on Law No.20 of 2003 article 37 on Sisdiknas (2003), curriculum KTSP social science subjects in 2006 aims to learners have the following capabilities: 
1. Know the concepts related to society and the environment.

2. Have basic skills for logical and critical thinking, curiosity, inquiry, problem solving, and skills in social life.

3. Have a commitment and awareness of social values and humanity.

4. Have the ability to communicate, work together and compete in a pluralistic society, local, national, and global. (Gunawan, 2011).

Referring to Law No.20 of 2003 on Sisdiknas, researchers hope that social science subjects in elementary school can be understood by students and can be actualized in everyday life by students with Discovery Learning method in school. Implementation of Discovery Learning is expected students can use inductive reasoning to develop more enjoyable IPS learning.

Through the application of discovery methods using visual media, it is expected that grade 2 students can improve their visual ability on understanding Natural Resources and the Environment on thematic learning.

Based on the problems that developed above, this study focuses on the study of "Application of Discovery Methods in Improving Student's Visual Ability on Natural Resources and Environmental Subjects".

\section{A. Foundation of Research}

The things underlying this study are based on general research data previously disclosed and field observation notes in general where the learning process in elementary school is still far from expectations that should be able to further enable students through activities that can find something new. In learning Social science in the class for example, often less meaningful learning process for students. Students just sit sweet and silent, listen to the teacher's explanation, many teachers stand in front of the class explain the subject matter, and teachers tend to be more active lectures themselves. There is also an indication that teacher pedagogical practice is less appropriate to the topic and does not have an appropriate focus so that experience, visual understanding does not develop optimally.

The 21st Century National Education Paradigm states that the strategy of achieving education in the future one of them is by applying different learning methods in elementary school. This method holds to the principle that each individual is unique and has their own talents, so the learning method must take into account the diversity of "learning style" of each individual. Through different learning activities through the use of this method of discovery, both students and teachers are expected to develop more visually.

74 | Implementation of Inventory Method in Improving Visual Students Visual Learning on Natural Responsibility Resources and Environmental Survival 
Learning models that emphasize these characteristics and diversity need to be developed. Examples of learning models in question include PBL (Problem Based Learning) and methods of discovery. In addition, emphasis should be placed on cooperative learning models between individuals to improve their interpersonal and social competence, such as: Cooperative Learning and Collaborative Learning through learning activities based on discovery methods.

The things that happened that have been expressed before can be understood as the truth that really happened in elementary school. Thus there is a need for mentoring and research that can provide examples of various learning with discovery methods so that the students and teachers of elementary school are more enthusiastic and open to study harder. Through this research, we hope to find meaningful findings on the extent to which methods of discovery have been made to improve students' ability in their visual aspects. The specific problems we may face are the reluctance of Primary School students and teachers to our presence, but through collaborative discussions, we believe it will be resolved and this research will give deep meaning to all of us.

The method of discovery is a learning model based on the constructivism approach of Piaget and Vygotsky. Constructivism understands the essence of learning as a human activity of building or creating knowledge by trying to give meaning to knowledge according to experience (Nurohman: 2008).

The method of discovery is a model designed to engage students in digging information and inquiring, performing and finding, collecting data and analyzing and making their own conclusions. In this model students are given the freedom in constructing thoughts and findings during the activity so that students do themselves without the burden, fun and high motivation so that learning will be more meaningful. The method of discovery of learning emphasizes the development of reasoning, model building, its interrelationship with real-world applications or daily life and can make students have direct experience, so as to overcome learning problems such as difficulty in recalling the subject matter (Starrett and Morcos, 2001); (Raviv Daniel, 2004); And (Atles and Ali, 2011).

Characteristics of the method of discovery are: independent, mutually supportive, happy, passionate learning, integrated learning, using multiple sources, active, fun, not boring, sharing with friends, critical and creative students. The method of discovery can also provide an in-depth appreciation of what is learned, so that what is obtained by students is not easily forgotten because students acquire such knowledge directly through their own experience. By learning the method of discovery, students can appreciate the concepts taught 
by the teacher, the students can prove facts and concepts, and also encourage the students 'curiosity in more depth, so it tends to arouse students' desire to conduct research to gain observation and experience in the scientific process. Through the method of discovery, students can also benefit from: increase interest, motivation, strengthen memories, can overcome the problem of learning difficulties, avoid misunderstandings, get feedback from students and connect the concrete and abstract. (Weinberg, Ithaca and Thomas, 2009) and (Ivers and Whitney, 2009).

In the implementation of learning with the method of this invention to be truly effective need to pay attention to several things include: the visual aspect. Discovery methods make learners become independent, dare to ask questions, explore curiosity and become creative learners. A teacher can and should be able to give the student experience, at least ten minutes to the student where the student can feel, hear, see, and act on the subject to be taught for the rest of the time. This can create a fun atmosphere, reduce student boredom and learn more effectively.

\section{B. Formulation of the problem}

Based on the background that has been disclosed before, this research is directed to answer the problem as follows: "How Use of Discovery Method in Improving Visual Aspect Ability of Elementary School Students on Natural Resources and Environment Subject?". Our problems are detailed through the following research questions:

1. Can the Discovery Method improve the visual aspect of elementary students on the subject of Natural Resources and the Environment?

2. How big is the visual aspect improvement of elementary school students doing the learning through discovery method?

\section{Limitations of Research}

Based on the formulation of the problems that have been disclosed, it is necessary to limit the research to make this research more focused. The research limits are given as follows:

1. This research is limited to the social science teaching of elementary school.

2. The subject of the research is the students of grade 2 Primary School.

3. Learning is done through the use of thematic learning by the method of discovery.

4. The measured learning outcome is the ability of the visual aspect through the test of learning outcomes in the form of a description.

76 | Implementation of Inventory Method in Improving Visual Students Visual Learning on Natural Responsibility Resources and Environmental Survival 


\section{Research purposes}

The purpose of this study as follows:

1. To obtain an effective and efficient learning method that can improve the visual aspect ability of elementary school students.

2. To obtain a Student Worksheet tool for learning of discovery methods developed to guide students for their visual abilities to develop optimally.

3. To obtain an appropriate evaluation tool to be able to test the achievement of students' visual aspect abilities through the study of the method of invention given.

4. To obtain information on the feasibility of the method of invention given in its implementation.

5. To facilitate the teacher in delivering the learning materials should be given by the method of discovery.

6. To direct elementary school students in gaining more knowledge and experience through learning of discovery methods.

\section{E. Output Target}

The expected output target for this research activity is as follows:

1. Manual manual for mechanism of how to develop learning activity of discovery method in elementary school.

2. The results of research that can be used as material as data and facts when this activity is done, can be a material of further study for the material of final project completion (thesis) / research and can be published nationally through the available educational journals.

3. There is a follow-up research program for the next year of program development based on program evaluation, whether conducted by the monev team, or elementary school.

4. As a study material, as for the follow-up research program that can be done as follows: the increase of students and teachers who do the learning with the method of discovery.

5. Increased understanding of learning at elementary level for students, as well as teachers.

The greatest part of social Science that students learn in school is not obtained through discovery, but is obtained through notices (by lecture / expository), reading, imitating, seeing, observing, and the like. The method of discovery is one method of learning to find and discover on their own. Learning in this system the teacher presents the lesson material in the final form, but the students are given the opportunity to seek and find it 
themselves and use problem-solving techniques (Djamarah and Zain, 2002).Broadly speaking the procedure as follows:

1. Simulation

Teachers begin to ask questions by asking students to read / listen to the descriptions that contain the problem.

2. Problem Statement

Students are given the opportunity to identify problems. Most chose it that was considered most attractive and flexible to solve. The selected problem must then be formulated in the form of a question / hypothesis, ie statement (statement) as a temporary answer to the question posed.

\section{Data Collection}

To answer the questions / prove whether or not this hypothesis is true, students are given the opportunity to collect (collect) various objects, interviews with resource person self-test and so on.

\section{Data Processing}

All reading, interview, observation, etc. information are all randomized, classified, tabulated, even where necessary in a certain way and interpreted at a certain level of need.

\section{Verification}

Proof based on the results of processing and interpretation / information that there is a statement / hypothesis that has been formulated earlier then checked, whether answered / no, whether proven or not.

\section{Generalization}

The next stage based on student verification learns to draw certain conclusions / generalizations. According to Sudirman et al. (1991) that the method of discovery is a way of presenting a lesson involving many students in mental processes in the context of its discovery.Furthermore Ruseffendi (1991) explains that "the method (teaching) of discovery is a teaching method that governs teaching in such a way that the child acquires knowledge that he has not previously known through notification, partially or entirely found alone."

\section{METHODS}

In learning a lot of media that we can actualize in learning so that students can receive the subject matter well and fun. One of them is visual media or image media. According to Udik (2008) "The successful use of visual based media is determined by the quality and effectiveness of the visual materials and the graph itself. This can be achieved by organizing 
and organizing ideas that arise and plan them carefully. "Researchers will conduct research using visual media because not all primary schools have the same facilities that have advanced technology and not all teachers can operate advanced technology if using Audio visual media.

In order for learning to use visual media to run smoothly it is necessary to have an appropriate learning method as a bridge so that students can receive the subject matter well and fun. One such method is the Discovery Learning or discovery method, where students can find their own core of the learning process in school and the teacher only provides reinforcement and concludes in the process of learning activities undertaken.

In addition Mulyasa (in Fate, 2012) states that discovery is a learning strategy that emphasizes direct experience in the field, without having to always rely on the theories of learning contained in the textbook guide. The researcher hopes that there is a correlation between the method of discovery with the current curriculum system, the national curriculum.

The research will be carried out in several stages:

1. Planning,

2. Implementation (action),

3. Observation,

4. Reflection

The subjects of this study are the students of second grade odd semester amounted to 35 people consisting of students 18 men and 17 female students held in Cibabat Mandiri 3 Primary School, North Cimahi Subdistrict, Cimahi City. Class II is chosen as the subject of research because students need immediate action to improve student activity and learning outcomes by applying learning discovery approach with visual-assisted media.

The study was conducted in two cycles so that there will be significant results. In each cycle the study consists of two meetings, one meeting for the implementation of learning and one meeting for the test of learning outcomes. The method used in data collection in this study is a test method that is carried out at the end of the cycle by using the test results to learn to improve learning outcomes Social science. The test used is a written test. In this study the instrument used is the test of learning outcomes in the form of multiple choice tests.

For the purposes of collecting data related to the observer's task, the researcher and the partner researcher determine the necessary data collection techniques:

1. Observation Technique

Observations used are direct observation so as to know the actual state of the class and observe the activities of teachers and students during the learning process takes place.

Implementation of Inventory Method in Improving Visual Students Visual Learning on Natural Responsibility Resources and Environmental Survival $\mid 79$ 


\section{Techniques}

The test is done to find out the students' understanding on the subject matter of Social Material Appearance.

\section{Data Analysis Techniques}

Data processing is an attempt by researchers to accurately summarize data that has been collected in a form that can be trusted and true. Data that have been collected by both researchers and partner researchers will be processed and analyzed qualitatively-descriptive.

\section{RESULTS AND DISCUSSION}

This research activity has been carried out in SDN Cibabat Mandiri 3 Kota Cimahi and produce some findings that fit with the title of "Use of MP to Improve Visual Aspect Ability of Elementary School Students on Natural Resources and LH Resources". As explained in the previous chapter, this study aims to improve the visual aspect abilities of elementary school students through the learning of MP. Results and outcomes achieved in this study as follows. The research findings obtained in the form of findings of students' visual research and interview data. The findings are further analyzed and interpreted.

\section{A. Data on Student Learning Results}

The data obtained to determine student learning outcomes in the form of preliminary and final tests. Initial test is done to determine the students 'initial ability before the MP learning is given and the learning result obtained in the final test is used as a comparison to know the students' success in following the learning using MP. Initial test result data are presented in the following table:

Table 1

Research Data of Comparative Class (Non-Discovery)

\begin{tabular}{ccccccc}
\hline No & \multicolumn{2}{c}{ Value } & \multicolumn{2}{c}{ Percentage } & Gain (\%) & Student Group \\
\cline { 2 - 5 } & \multicolumn{2}{c}{ Pretes } & Postes & Pretes (\%) & Postes (\%) & \\
\hline 1 & 0,50 & 2,50 & 5,0 & 25,0 & 20,0 & Low \\
\hline 2 & 0,75 & 2,50 & 7,5 & 25,0 & 17,5 & Low \\
\hline 3 & 1,00 & 2,50 & 10,0 & 25,0 & 15,0 & Low \\
\hline 4 & 1,00 & 5,50 & 10,0 & 55,0 & 45,0 & Low \\
\hline 5 & 1,50 & 7,00 & 15,0 & 70,0 & 55,0 & Low \\
\hline 6 & 1,50 & 4,25 & 15,0 & 42,5 & 27,5 & Low \\
\hline 7 & 1,75 & 3,25 & 17,5 & 32,5 & 15,0 & Low \\
\hline
\end{tabular}

80 Implementation of Inventory Method in Improving Visual Students Visual Learning on Natural Responsibility Resources and Environmental Survival 
P-ISSN: 2580-9326

E-ISSN: 2580-7714
Journal of Elementary Education Volume 1, Number 1, September 2017

\begin{tabular}{|c|c|c|c|c|c|c|}
\hline \multirow[t]{2}{*}{ No } & \multicolumn{2}{|c|}{ Value } & \multicolumn{2}{|c|}{ Percentage } & \multirow[t]{2}{*}{ Gain $(\%)$} & \multirow[t]{2}{*}{ Student Group } \\
\hline & Pretes & Postes & Pretes (\%) & Postes (\%) & & \\
\hline 8 & 1,75 & 5,50 & 17,5 & 55,0 & 37,5 & Low \\
\hline 9 & 1,75 & 6,25 & 17,5 & 62,5 & 45,0 & Low \\
\hline 10 & 2,00 & 5,50 & 20,0 & 55,0 & 35,0 & Medium \\
\hline 11 & 2,00 & 5,50 & 20,0 & 55,0 & 35,0 & Medium \\
\hline 12 & 2,25 & 6,00 & 22,5 & 60,0 & 37,5 & Medium \\
\hline 13 & 2,25 & 8,25 & 22,5 & 82,5 & 60,0 & Medium \\
\hline 14 & 2,50 & 4,00 & 25,0 & 40,0 & 15,0 & Medium \\
\hline 15 & 2,50 & 2,75 & 25,0 & 27,5 & 2,5 & Medium \\
\hline 16 & 2,75 & 3,75 & 27,5 & 37,5 & 10,0 & Medium \\
\hline 17 & 2,75 & 6,50 & 27,5 & 65,0 & 37,5 & Medium \\
\hline 18 & 3,00 & 4,75 & 30,0 & 47,5 & 17,5 & Medium \\
\hline 19 & 4,50 & 1,75 & 45,0 & 17,5 & $-27,5$ & Medium \\
\hline 20 & 4,75 & 8,25 & 47,5 & 82,5 & 35,0 & Medium \\
\hline 21 & 5,25 & 6,25 & 52,5 & 62,5 & 10,0 & Medium \\
\hline 22 & 5,25 & 8,50 & 52,5 & 85,0 & 32,5 & Medium \\
\hline 23 & 5,50 & 5,25 & 55,0 & 52,5 & $-2,5$ & Medium \\
\hline 24 & 5,75 & 6,00 & 57,5 & 60,0 & 2,5 & Medium \\
\hline 25 & 5,75 & 6,00 & 57,5 & 60,0 & 2,5 & Medium \\
\hline 26 & 5,75 & 7,25 & 57,5 & 72,5 & 15,0 & Medium \\
\hline 27 & 6,00 & 9,50 & 60,0 & 95,0 & 35,0 & Medium \\
\hline 28 & 6,00 & 9,50 & 60,0 & 95,0 & 35,0 & Medium \\
\hline 29 & 6,25 & 5,75 & 62,5 & 57,5 & $-5,0$ & Medium \\
\hline 30 & 6,25 & 8,50 & 62,5 & 85,0 & 22,5 & High \\
\hline 31 & 6,25 & 7,00 & 62,5 & 70,0 & 7,5 & High \\
\hline 32 & 6,25 & 7,75 & 62,5 & 77,5 & 15,0 & High \\
\hline 33 & 6,25 & 6,75 & 62,5 & 67,5 & 5,0 & High \\
\hline 34 & 6,50 & 7,25 & 55,0 & 72,5 & 7,5 & High \\
\hline 35 & 7,00 & 8,00 & 50,0 & 80,0 & 11,0 & High \\
\hline & Avarag & & 30,0 & 35,0 & 30,0 & \\
\hline
\end{tabular}


Table 2

Data of Class MP Study Results

\begin{tabular}{|c|c|c|c|c|c|c|}
\hline \multirow[t]{2}{*}{ No } & \multicolumn{2}{|c|}{ Value } & \multicolumn{2}{|c|}{ Percentage } & \multirow[t]{2}{*}{ Gain $(\%)$} & \multirow[t]{2}{*}{ Student Group } \\
\hline & Pretes & Postes & Pretes $(\%)$ & Postes (\%) & & \\
\hline 1 & 1,50 & 5,50 & 15,0 & 55,0 & 40,0 & Low \\
\hline 2 & 2,20 & 6,25 & 22,0 & 62,5 & 40,5 & Low \\
\hline 3 & 2,70 & 9,50 & 27,0 & 95,0 & 68,0 & Low \\
\hline 4 & 3,00 & 7,00 & 30,0 & 70,0 & 40,0 & Low \\
\hline 5 & 3,00 & 7,75 & 30,0 & 77,5 & 47,5 & Low \\
\hline 6 & 3,00 & 8,25 & 30,0 & 82,5 & 52,5 & Low \\
\hline 7 & 3,00 & 8,50 & 30,0 & 85,0 & 55,0 & Low \\
\hline 8 & 3,00 & 8,00 & 30,0 & 80,0 & 50,0 & Low \\
\hline 9 & 3,20 & 9,00 & 32,0 & 90,0 & 58,0 & Low \\
\hline 10 & 3,20 & 6,75 & 32,0 & 67,5 & 35,5 & Low \\
\hline 11 & 3,20 & 8,50 & 32,0 & 85,0 & 53,0 & Medium \\
\hline 12 & 3,20 & 9,75 & 32,0 & 97,5 & 65,5 & Medium \\
\hline 13 & 3,50 & 9,00 & 35,0 & 90,0 & 55,0 & Medium \\
\hline 14 & 3,50 & 8,00 & 35,0 & 80,0 & 45,0 & Medium \\
\hline 15 & 3,50 & 8,75 & 35,0 & 87,5 & 52,5 & Medium \\
\hline 16 & 3,70 & 9,75 & 37,0 & 97,5 & 60,5 & Medium \\
\hline 17 & 3,70 & 9,75 & 37,0 & 97,5 & 60,5 & Medium \\
\hline 18 & 4,00 & 9,50 & 40,0 & 95,0 & 55,0 & Medium \\
\hline 19 & 4,00 & 9,00 & 40,0 & 90,0 & 50,0 & Medium \\
\hline 20 & 4,25 & 8,50 & 42,5 & 85,0 & 42,5 & Medium \\
\hline 21 & 4,25 & 8,00 & 42,5 & 80,0 & 37,5 & Medium \\
\hline 22 & 4,50 & 9,00 & 45,0 & 90,0 & 45,0 & Medium \\
\hline 23 & 4,75 & 8,00 & 47,5 & 80,0 & 32,5 & Medium \\
\hline 24 & 4,75 & 8,00 & 47,5 & 80,0 & 32,5 & Medium \\
\hline 25 & 4,75 & 7,50 & 47,5 & 75,0 & 27,5 & Medium \\
\hline 26 & 4,75 & 9,25 & 47,5 & 92,5 & 45,0 & Medium \\
\hline 27 & 5,00 & 8,25 & 50,0 & 82,5 & 32,5 & Medium \\
\hline 28 & 5,00 & 9,00 & 50,0 & 90,0 & 40,0 & Medium \\
\hline 29 & 5,00 & 8,75 & 50,0 & 87,5 & 37,5 & Medium \\
\hline 30 & 5,50 & 9,00 & 55,0 & 90,0 & 35,0 & Medium \\
\hline 31 & 5,50 & 9,25 & 55,0 & 92,5 & 37,5 & High \\
\hline 32 & 6,00 & 9,00 & 60,0 & 90,0 & 30,0 & High \\
\hline 33 & 6,25 & 9,50 & 62,5 & 95,0 & 32,5 & High \\
\hline 34 & 6,25 & 9,25 & 62,5 & 92,5 & 30,0 & High \\
\hline 35 & 6,50 & 9,75 & 75,0 & 97,5 & 42,5 & High \\
\hline
\end{tabular}




\begin{tabular}{|c|c|c|c|c|c|c|}
\hline \multirow[t]{2}{*}{ No } & \multicolumn{2}{|c|}{ Value } & \multicolumn{2}{|c|}{ Percentage } & \multirow[t]{2}{*}{ Gain (\%) } & \multirow[t]{2}{*}{ Student Group } \\
\hline & Pretes & Postes & Pretes (\%) & Postes (\%) & & \\
\hline \multicolumn{3}{|c|}{ Avarage } & 60 & 95,0 & 70 & \\
\hline
\end{tabular}

Based on the above table, the average score of the initial test obtained by the comparative class students (NP) is 20 with the highest score of 60 and the lowest 5 , whereas the MP class the average score of the initial test 61 with the highest score of 75 and the lowest 10. After tested statistically, The average score of the initial test of the NP class with the MP class, the comparison is not much different and the second homogeneous test score score, it indicates that the initial ability of the two classes before the treatment is given is the same.

Based on the above table, the average score of the final test obtained by the NP class students is 35 with the highest score of 70 and the lowest is 15 , whereas the MP class the average score of the final test is 95 with the highest score of 98 and the lowest 50. If compared between the average score The second end of the test class, the final grade of MP is greater than the NP class.

The NP class gain scores and the MP class are obtained from the difference between the initial test result and the final test. Based on the above table, the average gain score of the NP class is 20 with the highest value of 50 and the lowest -27.5 , while the average gain of the MP class is 55 with the highest value of 78 and the lowest is 37 . When compared between the average score of the second gain Class, the average gain score of the MP class is greater than the NP class. This suggests that there has been an increase in learning outcomes in MP classes that use discovery-based learning methods as a learning method.

\section{B. Statistical Test Results}

This statistical test is conducted to know the difference of learning outcomes between classes that were given learning using MP with classes that were given NP lesson as a comparison class. Test results for final score as follows:

Table 3

Analysis of Learning Outcomes Class NP and Class MP Students Group Low

\begin{tabular}{|c|c|c|}
\hline \multirow[t]{2}{*}{ No. } & \multicolumn{2}{|c|}{$\%$ Gain } \\
\hline & NP Class & MP Class \\
\hline 1 & 20,0 & 40,0 \\
\hline 2 & 17,0 & 40,5 \\
\hline 3 & 15,0 & 68,0 \\
\hline 4 & 45,0 & 40,0 \\
\hline
\end{tabular}




\begin{tabular}{|c|c|c|}
\hline \multirow[t]{2}{*}{ No. } & \multicolumn{2}{|c|}{$\%$ Gain } \\
\hline & NP Class & MP Class \\
\hline 5 & 55,0 & 47,5 \\
\hline 6 & 27,0 & 52,5 \\
\hline 7 & 15,0 & 55,0 \\
\hline 8 & 37,0 & 50,0 \\
\hline 9 & 40,0 & 58,0 \\
\hline 10 & 35,0 & 35,5 \\
\hline varage & 30,0 & 50,0 \\
\hline
\end{tabular}

There is a significant difference in learning outcomes between low group students in the NP class and the MP class. MP learning can increase the percentage of students' learning outcomes from the low group from $30 \%$ to $50 \%$.

Table 4

Analysis of Learning Outcomes MD Class and Class MP Student Group Medium

\begin{tabular}{|c|c|c|}
\hline \multirow[t]{2}{*}{ No. } & \multicolumn{2}{|c|}{ \%Gain } \\
\hline & MD Class & MP Class \\
\hline 1 & 35,0 & 53,0 \\
\hline 2 & 37,0 & 65,5 \\
\hline 3 & 60,0 & 55,0 \\
\hline 4 & 15,0 & 45,0 \\
\hline 5 & 2,5 & 52,5 \\
\hline 6 & 10,0 & 60,5 \\
\hline 7 & 37,5 & 60,5 \\
\hline 8 & 17,5 & 55,0 \\
\hline 9 & $-27,5$ & 50,0 \\
\hline 10 & 35,0 & 42,5 \\
\hline 11 & 10,0 & 37,5 \\
\hline 12 & 32,5 & 45,0 \\
\hline 13 & $-2,5$ & 32,5 \\
\hline 14 & 2,5 & 32,5 \\
\hline 15 & 2,5 & 27,5 \\
\hline 16 & 15,0 & 45,0 \\
\hline 17 & 30,0 & 32,5 \\
\hline 18 & 35,0 & 40,0 \\
\hline 19 & $-5,0$ & 37,0 \\
\hline 20 & 22,0 & 35,0 \\
\hline arag & 20,0 & 45,0 \\
\hline
\end{tabular}

84 Implementation of Inventory Method in Improving Visual Students Visual Learning on Natural Responsibility Resources and Environmental Survival 
There was a significant difference in learning outcomes between the moderate group students in the MD class and the MP class. MP learning can increase the percentage of students' learning outcomes in moderate groups from $20 \%$ to $45 \%$.

Table 4

\section{Analysis of Learning Outcomes of Class of MD and Class of High Student Group of} Students

\begin{tabular}{ccr}
\hline No. & \multicolumn{2}{c}{ \%Gain } \\
\cline { 2 - 3 } & NH Class & Hypertext \\
Class \\
\hline 1 & 7,5 & 37,5 \\
\hline 2 & 15,0 & 30,0 \\
\hline 3 & 5,0 & 32,5 \\
\hline 4 & 7,5 & 30,0 \\
\hline 5 & 10,0 & 32,0 \\
\hline Avarage & 10,0 & 30,0
\end{tabular}

There is a significant difference in learning outcomes between high group students in the MD class and the MP class. MP Learning can increase the percentage of high student learning outcomes from $10 \%$ to $30 \%$.

Table 5

Analysis of Classroom Learning Results of MD and Class MP

\begin{tabular}{|c|c|c|}
\hline \multirow[t]{2}{*}{ No. } & \multicolumn{2}{|c|}{$\%$ Gain } \\
\hline & MD Class & MP Class \\
\hline 1 & 20,0 & 40,0 \\
\hline 2 & 17,5 & 40,5 \\
\hline 3 & 15,0 & 68,0 \\
\hline 4 & 45,0 & 40,0 \\
\hline 5 & 55.0 & 47,5 \\
\hline 6 & 27,5 & 52,5 \\
\hline 7 & 15.0 & 55.0 \\
\hline 8 & 37,5 & 50.0 \\
\hline 9 & 45.0 & 58.0 \\
\hline 10 & 35.0 & 35,5 \\
\hline 11 & 35.0 & 53.0 \\
\hline 12 & 37,5 & 65,5 \\
\hline 13 & 60.0 & 55.0 \\
\hline 14 & 15.0 & 45.0 \\
\hline 15 & 2,5 & 52,5 \\
\hline
\end{tabular}




\begin{tabular}{|c|c|c|}
\hline \multirow[t]{2}{*}{ No. } & \multicolumn{2}{|c|}{ \% Gain } \\
\hline & MD Class & MP Class \\
\hline 16 & 10.0 & 60,5 \\
\hline 17 & 37,5 & 60,5 \\
\hline 18 & 17,5 & 55.0 \\
\hline 19 & $-27,5$ & 50.0 \\
\hline 20 & 35.0 & 42,5 \\
\hline 21 & 10.0 & 37,5 \\
\hline 22 & 32,5 & 45.0 \\
\hline 23 & $-2,5$ & 32,5 \\
\hline 24 & 2.0 & 32,5 \\
\hline 25 & 2.0 & 27,5 \\
\hline 26 & 15.0 & 45.0 \\
\hline 27 & 35.0 & 32,5 \\
\hline 28 & 35.0 & 40.0 \\
\hline 29 & -5.0 & 37,5 \\
\hline 30 & 22,5 & 35.0 \\
\hline 31 & 7,5 & 37,5 \\
\hline 32 & 20.0 & 30.0 \\
\hline 33 & 5,0 & 52,5 \\
\hline 34 & 7,5 & 30,0 \\
\hline 35 & 10,0 & 32,5 \\
\hline varage & 20,0 & 44,0 \\
\hline
\end{tabular}

There is a significant difference in learning outcomes between the MD classes and the MP classes. MP learning can increase the percentage of learning outcomes from $20 \%$ to $44 \%$.

\section{Achieved Outcomes}

From the results of research activities that have been implemented in SDN Cibabat Mandiri 3 Kota Cimahi obtained some outcomes according to the plan that has been described in the previous chapter. The results are as follows:

Table 6

Research Survey

\begin{tabular}{clc}
\hline No. & \multicolumn{1}{c}{ Output Type } & Indicator \\
\hline 1 & Scientific publications in journals & Accepted \\
\hline 2 & Publication on mass media (print / electronic) & Draft \\
\hline 3 & Improved understanding and skills of the community & Done \\
\hline 4 & Services, models, social engineering, systems, products / goods & Done \\
\hline
\end{tabular}


Outcomes that have been implemented as the basis for the activities of elementary school teachers in Cibabat Mandiri Primary School 3. The next issue is scientific publication in Journals / proceedings to be published in September 2017 to the Journal of Primaryedu STKIP Siliwangi Bandung.

In addition to the outcomes that have been delivered, there are several outpourings among them as follows:

1. The data of other research results can be used as material as data and facts for the material of final project completion (thesis) / research and can be published.

2. There is a follow-up program for the next year of program development based on program evaluation, whether conducted by the monev team or elementary school.

3. Increased students and elementary school teachers who are doing MP learning.

4. Increased understanding of learning at elementary level for students, as well as teachers.

\section{CONCLUSION}

Based on the results of the implementation of research that has been implemented in Cibabat Mandiri 3 Primary School Cimahi City, it can be concluded things as follows:

1. Learning MP can improve the visual aspect ability of elementary school students on the subject of Natural Resources and Environment.

2. Increased student learning outcomes of the MP class is greater than the NP class (24\%) and there are significant differences in learning outcomes among each student group.

\section{ACKNOWLEDGMENTS}

The Chief Researcher expressed his gratitude to the Mandiri Research Team, SDN Cibabat Mandiri 3 for the trust given, and RamdhanWitarsa, M.Pd. as mentors in elementary education STKIP Siliwangi Bandung. We will keep our trust and mother confidence and will continue to develop in future studies.

\section{REFERENCES}

Aho, S. (1998).The teasers and the teased pupils at school. Scandinavian Journal of Educational Research, 42(3), 309-318.

Barnett, M. A., Burns, S. R., Sanborn, F. W., Bartel, J. S., \& Wilds, S. J. (2004). Antisocial and prosocial teasing among children: Perceptions and individual differences. Social Development, 13, 292-310. 
Bentley, K. M., \& Li, A. K. F. (1995). Bully and victim problems in elementary schools and student's beliefs about aggression. Canadian Journal of School Psychology, 11, 153165.

Bollmer, J. M., Harris, M. J., Milich, R., \&Georgesen, J. C. (2003).Taking offense: Effects of personality and teasing history on behavioral and emotional reactions to teasing. Journal of Personality, 71, 557-603.

Bosacki, S., Zopito, A. M., \& Dane, A. V. (2006). Voices from the classroom: Pictorial and narrative representations of children's bullying experiences. Journal of Moral Education, 35(2), 231-245.

Burke, C. (2008). 'Play in focus': Children's visual voice in participative research. In P. Thomson (Ed.), Doing visual research with children and young people (pp. 23-36). London: Routledge.

Clandinin, D. J., \& Connelly, F. M. (2000). Narrative inquiry: Experience and story in qualitative research (1st ed.). San Francisco, CA: Jossey-Bass Inc.

Clark, A. (2007). A hundred ways of listening: Gathering children's perspectives of their early childhood environment. Young Children, 62(3), 76-81.

Clark, A. (2005). Listening to and involving young children: A review of research and practice. Early Child Development and Care, 175(6), 489-505.

Coates, E., \& Coates, A. (2006).Young children talking and drawing. International Journal of Early Years Education, 14(3), 221-241.

Cohen, L., Manion, L., \& Morrison, K. (2000). Research methods in education (5th ed.). London: RoutledgeFalmer.

Craig, W. M., \&Pepler, D. J. (1997).Observations of bullying and victimization in the school yard. Canadian Journal of School Psychology, 13, 41-59.

Cranham, J., \& Carroll, A. (2003). Dynamics within the Bully/Victim Paradigm: A qualitative analysis. Educational Psychology in Practice, 19(2), 113.

Dahlberg, G., \& Moss, P. (2005).Ethics and politics in early childhood education. New York: RoutledgeFalmer.

David, T. (1999). Young children learning. London, UK: Sage Publications.

Diaz Soto, L. (2005). Children make the best theorists. In L. Diaz Soto \& B. Blue Swadener (Eds.), Power and voice in research with children (pp. 9-19). New York: Peter Lang Publishing.

Dockett, S., \& Perry, B. (2005).Researching with children: Insights from the Starting School Research Project. Early Child Development and Care, 175(6), 507-522.

Drew, P. (1987). Pro-faced receipts of teases. Linguistics, 25, 219-253.

Edwards, C., Gandini, L., \& Foreman, G. (Eds.) (1998). The hundred languages of children: The Reggio Emilia approach to early childhood education. Norwood, NJ: Ablex Publishing.

Einarsdottir, J., Dockett, S., \& Perry, B. (2009). Making meaning: Children's perspectives expressed through drawings. Early Child Development and Care, 179(2), 217-232.

Eisenberg, N. (1986). Teasing: Verbal play in two Mexicano homes.In B. B. Schieffelin\& E. Ochs (Eds.), Language socialization across cultures (pp. 182-198). Cambridge, MA: Cambridge University Press.

Ely, M., Vinz, R., Downing, M., \&Anzul, M. (1997). On writing qualitative research: Living by words. London: RoutledgeFalmer.

Evans, P., \& Fuller, M. (1996). 'Hello. Who am I speaking to?' Communicating with preschool children in educational research settings. Early Years Journal, 17(1), 17-20.

Freedman, J. S. (2002).Easing the teasing. Chicago: Contemporary Books. 
Froschl, M., \& Sprung, B. (2005). The anti-bullying and teasing book for preschool classrooms. Beltsville, MD: Gryphon House.

Furman, K., \& Thompson, J. K. (2002). Body image, teasing, and mood alterations: An experimental study of exposure to negative verbal commentary. International Journal of Eating Disorders, 42, 449-457.

Geertz, C. (1973). Thick description: Toward an interpretive theory of culture. In C. Geertz (Ed.), The interpretation of cultures (pp. 3-30). New York: Basic Books.

Harwood, D. (2008). The teasing phenomenon: Preschool siblings' experiences with teasing within their relationships. Canadian Children, 33(1), 10-16.

Irvin, L. K., Walker, H. M., Noell, J., \& Singer, G. H. (1992).Measuring children's social skills using microcomputer-based vidoedisk assessment. Behavior Modification, 16, 473-503.

Keltner, D., Capps, L., Kring, A. M., Young, R. C., \&Heerey, E. A. (2001).Just teasing: A conceptual analysis and empirical review. Psychological Bulletin, 127(2), 229-248.

Keltner, D., Young, R. C., Heerey, E. A., Oemig, C., \& Monarch, N. D. (1998).Teasing in hierarchical and intimate relationships. Journal of Personality and Social Psychology, 75(5), 1231-1247.

Lightner, R. M., Bollmer, J. M., Harris, M. J., Milich, R., \& Scrambler, D. J. (2000). What do you say to teasers? Parent and child evaluations of responses to teasing. Journal of Applied Developmental Psychology, 21(4), 403-427.

MacCoby, E. E. (1990). Gender and Relationships: A developmental account. American Psychologist, 45(4), 513-520.

Malti, T., Gasser, L., \&Buchmann, M. (2009).Aggressive and prosocial children's emotion attributions and moral reasoning. Aggressive Behavior, 35, 90-102.

Malti, T., \& Keller, M. (2009). The relation of elementary-school children's externalizing behaviour to emotion attribution, evaluation of consequences, and moral reasoning. European Journal of Developmental Psychology, 6(5), 592-614.

Martlew, M., \&Hodson, J. (1991). Children with mild learning difficulty in an integrated and in a special school: Comparison of behavior, teasing and teacher's attitudes. British Journal of Educational Psychology, 61, 355-372.

Mooney, A. M., Creeser, R., \& Blatchford, P. (1991).Children's views on teasing and fighting in junior schools. Educational Research, 33, 103-112.

Mooney, S., \& Smith, P. K. (1995).Bullying and the child who stammers. British Journal of Special Education, 22(1), 24-27. Olweus, D. (1993). Bullying at school: What we know and what we can do. Oxford, UK ; Cambridge, USA: Blackwell.

Rinaldi, C. (2006). In dialogue with Reggio Emilia: Listening, researching and learning. London: Routledge Press.

Ross, D. M. (1996). Childhood bullying and teasing: What school personnel, other professional, and parents can do. Alexandria, VA: American Counselling Association.

Sanders-Bustle, L. (2003). Image, inquiry, and transformative practice: Engaging learners in creative and critical inquiry through visual representation. New York: Peter Lang Publishing.

Schieffelin, B. B., \& Ochs, E. (1986). Teasing and shaming in Kaluli children's interactions. In B. B. Schieffelin\& E. Ochs (Eds.), Language socialization across cultures (pp. 165181). Cambridge, MA: Cambridge University Press.

Scrambler, D. J., Harris, M. J., \&Milich, R. (1998). Sticks and stones: Evaluations of responses to childhood teasing. Social Development, 7(2), 234-249. 
Shapiro, J. P., Baumeister, R. G., \& Kessler, J. W. (1991).A three component model of children's teasing: Aggression, humor, and ambiguity. Journal of Social and Clinical Psychology, 10(4), 459-472.

Straehle, C. A. (1993). "Samuel? Yes, dear?"Teasing and conversational rapport. In D. Tannen (Ed.), Framing in discourses (pp. 210-231). New York: Oxford University Press.

Tamm, M. (2000).The meaning of God for children and adolescents - a phenomenographic study of drawings. British Journal of Religious Education, 19(1), 33-44.

Tesch, R. (1987). Emerging themes: The researcher's experience. Phenomenology \& Pedagogy, 5(3), 230-241.

Walker, H. M., Colvin, G., \& Ramsey, E. (1995). Antisocial behavior in schools: Strategies and best practices. Pacific Grove, CA: Brooks/Cole.

Warm, T. R. (1997). The role of teasing in development and vice versa. Journal of Developmental and Behavioral Pediatrics, 18, 97-102.

Whitney, I., \& Smith, P. K. (1993).A survey of the nature and extent of bullying in junior/middle and secondary schools. Educational Research, 35, 3-25. 